\title{
Semantic priming effects can be modulated by crosslinguistic interactions during second-language auditory word recognition
}

\begin{tabular}{|c|c|}
\hline Journal: & Bilingualism: Language and Cognition \\
\hline Manuscript ID & BLC-19-RA--0060.R3 \\
\hline Manuscript Type: & Research Article \\
\hline $\begin{array}{r}\text { Date Submitted by the } \\
\text { Author: }\end{array}$ & $\mathrm{n} / \mathrm{a}$ \\
\hline Complete List of Authors: & $\begin{array}{l}\text { Guediche, Sara; Basque Center on Cognition Brain and Language, } \\
\text { Baart, Martijn; Basque Center on Cognition Brain and Language; Tilburg } \\
\text { University, Cognitive Neuropsychology } \\
\text { Samuel, Arthur ; Stony Brook University, Psychology; Basque Center on } \\
\text { Cognition Brain and Language }\end{array}$ \\
\hline Content Areas: & Speech Perception, Mental Lexicon, Cognitive Psychology \\
\hline Linguistic Areas: & Lexical Semantics, Phonology, Semantics \\
\hline Methods: & Behavioural Measurements, Statistics: Mixed Effects Modelling \\
\hline Populations: & Multilinguals/Polyglots, Healthy Normal Subjects \\
\hline Languages: & Spanish, Basque \\
\hline
\end{tabular}




\section{Highlights:}

- Cognate status and semantic priming affect L2 auditory word recognition

- Cognates slow processing and also impair word recognition accuracy, in noise

- Semantic priming can override inhibitory effects of cognate status, in noise

- Long-term priming confirms cognate inhibition is not due to weaker lexical access

- Crosslinguistic interactions affect semantically-mediated flexibility in perception 
Semantic priming effects can be modulated by crosslinguistic interactions during second-language auditory word recognition*

Sara Guediche ${ }^{1}$, Martijn Baart ${ }^{1,2}, \&$ Arthur G. Samuel ${ }^{1,3,4}$

${ }^{1} \mathrm{BCBL}$. Basque Center on Cognition, Brain and Language

${ }^{2}$ Dept of Cognitive Neuropsychology, Tilburg University, The Netherlands

${ }^{3}$ Stony Brook University, NY

${ }^{4}$ Ikerbasque, Basque Foundation for Science

Running-head: Semantic and crosslinguistic effects on L2 word recognition

Address for Correspondence:

Corresponding author Sara Guediche

Basque Center for Cognition Brain and Language,

San Sebastian, Spain

Paseo Mikeletegi, 69, 2nd Floor

Donostia-San Sebastian Spain, 20009

s.guediche@bcbl.eu

*Acknowledgements. The authors thank Angela de Bruin for helping with the PsychoPy programming, Sara Martínez Narvarte, for help with the Basque semanticprime stimulus design, Paula Rios-López for providing the babble recording, Ainhoa Bastarrika-Iriarte for facilitating the automatization of noisy stimulus creation, Itziar Basterra, Amets Esnal, Larraitz Lopez for running participants in Basque, and Clara Martin, Sendy Caffarra, Angela de Bruin, and Effie Kapnoula for helpful discussions. In addition, we thank two anonymous reviewers for helpful comments during the revision process. This research was funded by the Spanish Ministry of Science and Innovation (Grant PSI2017-82563-P, awarded to A.G.S.), the Netherlands Organization for Scientific research (NWO Veni grant 275-89-027, awarded to M.B.), the Basque Government through the BERC 2018-2021 program, and the Spanish State Agency Severo Ochoa excellence accreditation SEV-2015-0490; Programme for Centres/Units of Excellence (awarded to the BCBL), and the European Union's Horizon 2020 research and innovation programme under the Marie Sklodowska-Curie grant agreement No. 799554. 


\begin{abstract}
The current study investigates how second language auditory word recognition, in early and highly proficient Spanish-Basque (L1-L2) bilinguals, is influenced by crosslinguistic phonological-lexical interactions and semantic priming. Phonological overlap between a word and its translation equivalent (phonological cognate status), and semantic relatedness of a preceding prime were manipulated. Experiment 1 examined word recognition performance in noisy listening conditions that introduce a high degree of uncertainty, whereas Experiment 2 employed clear listening conditions, with low uncertainty. Under noisy listening conditions, semantic priming effects interacted with phonological cognate status: for word recognition accuracy, a related prime overcame inhibitory effects of phonological overlap between target words and their translations. These findings are consistent with models of bilingual word recognition that incorporate crosslinguistic phonological-lexical-semantic interactions. Moreover, they suggest an interplay between L2-L1 interactions and the integration of information across acoustic and semantic levels of processing in flexibly mapping the speech signal onto the spoken words, under adverse listening conditions.
\end{abstract}

Keywords: Speech perception, speech in noise, lexical-semantics, cognate effects, lexical decision 


\section{Introduction}

Communicating in a second language requires the acquisition and use of linguistic structures that differ from one's native language. The degree to which a bilingual's two languages share commonalities along various linguistic dimensions (e.g, phonotactic, lexical, syntactic, etc.) impacts their ability to learn, produce, and comprehend a second language. While it is widely accepted that knowledge of one language inevitably influences the other, the underlying functional organization of bilingualism and the mechanisms underlying crosslinguistic effects are still largely unknown. The current study focuses on how auditory word recognition in a second language (in early and highly proficient Spanish-Basque (L1-L2) bilinguals) is influenced by crosslinguistic phonological-lexical overlap of words that share meaning (translation equivalents). In addition, we test whether semantic priming modulates these effects.

The potential crosstalk between languages has been examined using various theoretical, computational, and experimental approaches that test how different factors affect bilingual lexical access. One common experimental manipulation - cognate status - probes crosslinguistic lexical interactions by exploiting the orthographic-phonological form overlap of a word and its translation equivalent. Words that overlap in orthographic-phonological form across two languages and that share meaning, (such as the Spanish-English cognate pair Tren-Train), often produce facilitatory effects on the speed of visual word recognition, translation, naming, and word retrieval, when compared to Non-Cognates such as Mesa-Table (Caramazza \& Brones, 1979; Costa, Caramazza, \& Sebastian-Galles, 2000; Lemhölfer \& Dijkstra, 2004; Perea, Duñabeitia, \& Carreiras, 2008; Sheng, Lam, Cruz, \& Fulton, 2016; van Hell \& de Groot, 2008; van Hell \& Dijkstra, 2002). Effects of cognate status based on purely phonological overlap 
have also been observed, revealing facilitation of visual word recognition in language pairs with different scripts (Gollan, Forster, \& Frost, 1997).

Interestingly, in addition to facilitation effects, null or even inhibitory cognate effects can emerge when cognate type (identical vs. semi/partial, see Dijkstra \& van Heuven, 2002; Duyck, Van Assche, Drieghe, \& Hartsuiker, 2007), list composition (Poort \& Rodd, 2017), language context and semantic context (Dijkstra, van Hell, \& Brenders, 2015), task (lexical decision vs. language decision, see Bultena, Dijkstra, \& van Hell, 2014), proficiency (Blumenfeld, Bobb, \& Marian, 2016), and other linguistic characteristics (e.g., frequency, Peeters, Dijkstra, \& Grainger, 2013) are manipulated. The cognate facilitation effect itself has played a pivotal role in shaping models of bilingualism, but it is the factors modulating its effect (and the effect of other crosslinguistic manipulations) on lexical access that can clarify the more nuanced architectural differences among models.

The extensive literature examining the dynamics of bilingual and second language lexical access using cognate manipulations has mostly been focused on visual word recognition. In contrast, crosslinguistic effects on the lexical dynamics of bilingual and second language auditory word recognition are relatively understudied, despite the fact that language is primarily auditory in nature. Auditory word recognition depends on information that is 1) delivered over time, 2) inherently variable, and 3) susceptible to many common natural listening situations that degrade the quality of the signal, such as environmental noise. Native language comprehension is flexible enough to be relatively resilient to such signal degradations. Notably, second language auditory word recognition is impaired to a greater degree by noise as compared to native language word recognition, despite comparable performance in quiet listening conditions (Shi, 2012; 2014; Tabri, Chacra, \& Pring, 2015; Scharenborg and van Os, 2019). 
Nevertheless, bilinguals with high levels of L2 language proficiency (Schmidke et al., 2016; Scharenborg and van Os, 2019; Shi, 2014; 2015) and early age of acquisition (Kousaie et al., 2019; Reetzke, Sheng, \& Chandrasekaran, 2016) do not seem to be hindered by noise (although see Tabri, Abou Chacra, \& Pring, 2011, who show noiseinduced impairments even for highly proficient bi- and trilinguals).

Detrimental effects of noise during native word recognition are mitigated by the availability of contextually predictive sources of information that constrain lexical selection (e.g., semantic context, visual-articulatory context; Kalikow, Stevens, \& Elliott, 1977; Sumby \& Pollack, 1954). In contrast, second language processing does not seem to benefit as much from such perceptual flexibility (Golestani, 2009; HervaisAdelman, Pefkou, \& Golestani, 2014), unless the listeners are proficient bilinguals (e.g, Kousaie et al., 2019). Based on a study that found similar phoneme identification drops in performance for L2 compared to L1 listeners across increasing levels of noise (Cutler et al., 2004), Cutler (2005) suggested that the L2 challenge in noise is due to inflexibility of the L2 system due to an inability to make use of contextual information (e.g. transitional probabilities, vocabulary, etc.). Individual differences in the strength of the interactions among distinct hierarchically organized levels of processing (Kroll, van Hell, Tokowicz, \& Green, 2010) may affect the ability to integrate across information sources, impacting the perceptual mapping of the speech signal onto a lexical target. Indeed, the non-native listening deficit in noise does seem to be restricted to linguistic stimuli (Krizman et al., 2017), which supports an impairment in the facilitatory interactions among different levels of linguistic processing rather than a general perceptual deficit. Whether these hierarchical interactions in perception that seem to be critical for facilitating comprehension under adverse listening conditions are affected by crosslinguistic phonological interactions is not known. 
Taken together, the existing research on second language word recognition (both auditory and visual), in combination with research on speech perception/word recognition in noise (for both native and second language), suggests that accurate auditory word recognition in proficient bilinguals will be subject to effects of crosslinguistic phonological-lexical ("lateral") interactions, as well as cross-level lexical-semantic ("hierarchical") interactions. The goal of the current study is to further elucidate the functional organization of spoken language processing of a second language. Specifically, we examine how the interplay between crosslinguistic phonolexical lateral and lexical-semantic hierarchical interactions may impact auditory word recognition, under different listening conditions. To this end, two lexical decision experiments investigate effects of semantic priming, crosslinguistic phonologicallexical overlap, and their interplay in noisy (speech in speech babble, Experiment 1) and clear (Experiment 2) listening conditions, in a population of early/proficient balanced Spanish-Basque bilinguals. Listeners heard either a noisy or clear target and were asked to press one button if it was a word and another button if it was not a word. In both experiments, each target was preceded by a within-language prime, which was either semantically related or unrelated to the target word.

Because noisy targets (Experiment 1) entail high phonological uncertainty that negatively impacts lexical access, word recognition accuracy may be impaired. Accordingly, the conditions of Experiment 1 should produce robust semantic priming effects on second language word recognition accuracy (and processing speed). The conditions should also promote crosslinguistic interactions grounded in the phonological relationship between L2 word targets and their translation equivalents, which may be magnified by the uncertainty introduced by a noisy signal (as has been 
found for other within-language phonological manipulations), affecting word recognition accuracy.

To our knowledge, only one auditory word recognition study has manipulated the cognate status (phonological-lexical overlap) of a target together with semantic priming (Temnikova \& Nagel, 2015). The subjects were Russian-English bilinguals with either intermediate (Experiment 1) or high levels (Experiment 2) of L2 proficiency. The study employed a cross-language semantic priming paradigm conducted in quiet listening conditions, and found inhibitory effects (slower response times) for phonological cognates. There was also a significant facilitation effect of semantic priming on word recognition (faster response times). No interaction between semantic priming and cognate status was found, regardless of the listeners' proficiency level.

Based on those results, we expect to find effects of semantic priming and phonological cognate status in both experiments of the current study. The noisy conditions in Experiment 1 should impair word recognition accuracy, and semantic priming effects should therefore boost accuracy. In the clear listening conditions of Experiment 2, word recognition accuracy should be high, but processing speed may still be affected by semantic priming, producing faster response times. We also expect effects of phonological cognate status in both experiments. However, whether this crosslinguistic manipulation will result in inhibition or facilitation is not obvious: The one previous auditory study - which also manipulated semantic priming (Temnikova \& Nagel, 2015) - showed a cost for cognates, whereas most other (visual) studies found facilitation. Of particular interest in the current study is whether noisy listening conditions will induce an interaction between the two factors during auditory word recognition: Will cascading effects of noise, reliance on semantic context, and 
crosslinguistic interactions have an interdependent influence on the dynamics of lexical access?

The two languages spoken by our subjects - Spanish and Basque - have highly overlapping phonologies but belong to different language families (Indo-European and Pre-IndoEuropean, respectively). As a result, many words and their translation equivalents are phonologically distinct (e.g. silla, aulki (chair); Non-Cognates), but there are also many words that overlap in their phonological-lexical form (e.g., flor, lore (flower); Cognates). The Spanish-Basque language pair thus provides an ideal bilingual (L1-L2) system for revealing potential crosslinguistic effects of phonological-lexical interaction via semantics because it minimizes any influence of language-specific acoustic properties of speech sounds (that may be more common in other language pairs). According to some models (see Thomas \& van Heuven, 2005; van Heuven, 2005), these could introduce a potentially conflating factor that distinguishes the lexical items in one language vs. those in the other, biasing the activation of the target language. The degree to which acoustic-phonetic information is shared across languages has been shown to affect parallel language activation (Ju and Luce, 2004). In noise, such confounds could be exacerbated due to the degraded speech input.

\section{Beyond Recognition (Long-Term Repetition Effects)}

In addition to assessing immediate semantic and phonological effects on word recognition, each experiment also includes a final lexical decision test to probe longterm repetition priming of target stimuli. This test is intended to provide insight into the information that was activated during the initial presentation under the assumption that it will be re-activated more easily upon second presentation (e.g., Bowers et al., 2002). In this final test, listeners hear items that were previously presented in the first lexical decision task, as well as new items. Higher accuracy for the previously heard items is 
thought to reflect the item's level of activation during the initial lexical decision task. If phonological cognates activate the lexical form of the non-target language (either directly or indirectly through semantics), and if activation can be enhanced through crosslinguistic lexical (or phonological-semantic) resonance (Dijkstra, 2007; Dijkstra \& van Heuven, 2002; Dijkstra et al., 2018; Shook \& Marian, 2013), we should find a word recognition repetition effect that is greater for cognate items on the final lexical decision test.

\section{Experiment 1}

Noisy listening conditions challenge word recognition, especially when listening in a non-native language. Contextual information, such as a semantic prime, can help to resolve ambiguities in mapping the acoustic signal onto lexical representations, particularly under adverse listening conditions. Experiment 1 investigates the effect of semantic priming on recognition of L2 word targets that are presented in noise (speechbabble). Importantly, the L2 targets presented differ in the degree to which they share phonological-lexical overlap with (unpresented) native language translation equivalents (Non-Cognates, Partial-Cognates, or Identical-Cognates).

Although some studies indicate that the use of context is impaired in non-native listening, the few studies that have tested highly proficient bilinguals have shown successful facilitation (e.g., Kousaie et al., 2019). Given the high proficiency level of the Spanish-Basque bilinguals tested in the current study, we predict significant effects of semantic priming on word recognition accuracy. In addition, we predict significant effects of phonological-lexical overlap on word recognition performance. The existing literature does not indicate whether semantic priming (in noise) will interact with any 
crosslinguistic effects induced by the L2 target's phonological-lexical overlap with its L1 equivalent.

\subsection{Methods}

Participants. 20 (L1-L2) Spanish-Basque bilinguals participated (13 females; mean age $=23.1, \mathrm{SD}=2.8 ;$ mean age of Basque acquisition $=3.4, \mathrm{SD}=1.2 ;$ mean $\mathrm{BEST}$ picture-naming score ${ }^{1}$ in Basque (de Bruin, Carreiras, \& Duñabeitia, 2017) $=54.8$, SD $=5.1$ (scale $0-65)$. To better understand the profile of the bilinguals in the current study, and the potential generalizability of the results, we provide additional information about percentages of self-assessed language exposure and proficiency taken from the BCBL database (Participa) including mean \% L1 (Spanish) Exposure $=59, \mathrm{SD}$ $=10$, Speaking $=65, \mathrm{SD}=16$, Hearing $=59, \mathrm{SD}=12$, Reading $=60, \mathrm{SD}=20, \% \mathrm{~L} 2$ (Basque) Exposure $=31, \mathrm{SD}=11$, Speaking $=28, \mathrm{SD}=16$, Hearing $=32, \mathrm{SD}=13$, Reading $=29, \mathrm{SD}=18, \%$ Bilingual Language Context $=44, \mathrm{SD}=22$, and Interview Mark in Basque assessed by research assistant $(\max$ score 5$)=4.35, \mathrm{SD}=0.49$. Two participants were removed for not following instructions, along with one who did not reach a minimum overall performance of $50 \%$. One of the remaining 17 participants did not complete the long-term priming test and is therefore not included in those analyses.

Procedure. Participants performed a 2AFC (two alternative forced-choice) lexical decision task (LDT). The word/pseudoword responses were collected via two designated buttons. Participants listened to pairs of auditory stimuli (ISI = $300 \mathrm{~ms}$ ) consisting of a Basque word (the prime) followed by a Basque word or pseudoword (the target) presented in noise. Participants were instructed to press one button if the target was a word and another button if the target was a pseudoword. Participants were instructed to respond as quickly and as accurately as possible. A delay of 4 seconds 
from target onset was allotted before the next trial. Participants were given six practice trials prior to the start of the experiment.

After the experimental session, participants completed a language questionnaire before continuing with a long-term priming lexical decision test. With this long-term priming test, we assessed the degree to which semantic priming and crosslinguistic effects on word recognition accuracy persisted and affected subsequent word recognition accuracy by presenting old and new items. On each trial, participants listened to an (unprimed) item in noise that was a Basque word or pseudoword, and made another $2 \mathrm{AFC}$ lexical decision.

Stimulus presentation for the semantic priming task and for the long-term priming task was controlled using PsychoPy 1.38 (Peirce, 2007). The experiment was approved by the BCBL Ethics Review Board and complied with the guidelines of the Declaration of Helsinki. Participants provided written consent and were paid for their participation.

Stimuli. 320 Basque words were selected, including 160 Basque-Spanish Cognates and 160 Non-Cognates, to be used in both Experiment 1 and Experiment 2. In the main (first) lexical decision experiment, each participant heard 160 pseudowords and 160 words as targets, for a total of 320 trials; half of the words were Non-Cognates (80) and half were Cognates (80). The primes were in Basque (within-language), and were always presented in the clear. Primes were Non-Cognates that were not included in the Non-Cognate Target condition; they were either semantically related or unrelated to the (word) targets. To ensure there were no item differences contributing to the relatedness effect, targets were counterbalanced across the related and unrelated conditions, across participants. 
In the long-term priming test, participants heard all of the noisy targets (words and pseudowords) from the semantic priming paradigm again (this time without the prime); these were the 320 Old targets that were mixed with the speech babble noise, as before. There were 320 New targets (also presented in noise), comprised of 160 words and 160 pseudowords, for a total of 640 trials. Thus, half the stimuli presented in the long-term priming task were Old targets (from the previous lexical decision task) and half were New targets. Half of the Old words were Cognates, and half were NonCognates (that had previously appeared in either the Related or Unrelated condition). As was the case for the Old targets, half of the New targets were pseudowords and half were words. Old and New targets were counterbalanced across conditions across participants.

Semantic Relatedness of Within-Language Primes. The semantically related primes were designed by a native-Basque speaking research assistant. LSA (Latent Semantic Association) scores were measured from English translations available through lsa.colorado.edu (using the default topic space on the LSA website built from a corpus, "General_Reading_up_to_1 ${ }^{\text {st }}$ year_college (300 factors)") to ensure there was no significant difference between Cognate conditions. Unrelated primes were chosen by randomizing the Related primes. Targets were counterbalanced across participants, appearing both in the Related and Unrelated conditions. All of the stimuli were in Basque. The instructions were given to participants in Basque, by native Basque speakers.

Phonological Cognate Status. Critically, the Basque targets consisted of words that varied in the degree to which they overlapped in phonological form with their 
Spanish translation equivalent (words taken from BCBL database, see Duñabeitia et al., in prep). A phonological cognate score was calculated using a Levenshtein distance (corrected for length) based on the number of shared phonemes between a stimulus and its translation equivalent. Phonological Cognate Targets were defined as those words that share at least $50 \%$ phonological overlap with their translation equivalents ${ }^{2}$. Cognates were subdivided post-hoc into two additional categories: $100 \%$ for IdenticalCognates; $>50 \%<100 \%$ for Partial-Cognates. Non-Cognate Targets shared less than $50 \%$ phonological overlap with their translation equivalents.

Target word stimulus characteristics (frequency, age of acquisition, concreteness, or phonological neighborhood density (for those word targets that had measures available, $>90 \%$ of stimuli)) did not significantly differ across conditions (see Table 1 for examples and Supplementary Materials for the full set). However, the durations of the target sound files did significantly differ between the Cognate (mean = $1065 \mathrm{~ms}, \mathrm{SD}=139)$ and the Non-Cognate $($ mean $=981 \mathrm{~ms}, \mathrm{SD}=119)$ conditions. Therefore, target duration was included as a covariate in the analyses.

Noise Mixing Method. Targets were mixed with reversed Basque 6-talker speech babble $^{3}$ at a signal-to-noise ratio of $-5 \mathrm{~dB}$. Unique segments of babble noise were used for each word target and each pseudoword target for a given participant, using a preceding and following linear ramp-up and ramp-down of $50 \mathrm{~ms}$ of noise (thus noisy target duration was $100 \mathrm{~ms}$ longer than clear target duration, but the word or pseudoword duration was the same).

[Table 1] 


\subsection{Results}

Table 2 presents the average accuracies and reaction times (RTs) for the factorial crossing of target type (i.e., Cognate Status) with prime relatedness. Outliers (RTs $>2$ standard deviations from the mean, calculated for each participant individually), and trials with no response, were removed. In Experiment 1, we focus on accuracy because the babble noise brought word recognition down well below ceiling performance, as desired. Figure 1 displays the accuracy results. Performance on Cognates was worse than Non-Cognates when preceded by an Unrelated Prime but similar to Non-Cognates when preceded by a semantically Related prime. As Figure 1 shows, when the cognate stimuli are subdivided into two types (partial and identical), this pattern holds for both types.

[Table 2]

[Figure 1]

We conducted two analyses using generalized linear mixed effects models (implemented in R with glmer in the lme4 package) with accuracy (single trial data) as the dependent measure; participant and item were included as random factors. The first analysis contained a contrast effect code for Relatedness $(1,-1)$ and Cognate Status $(1,-$ 1). Because Dijkstra and van Heuven (2015) suggested potential differences between cognates with $100 \%$ lexical form overlap (identity cognates) and partial cognates, and the cognate list consisted of approximately half of each type of cognate, we conducted a second analysis in which Cognate Type was divided into two (finer-grained) contrast 
effect codes: Cognate Type Contrast 1 (Partial-Cognate 1, Non-Cognate -1) and Cognate Type 2 Contrast (Identical-Cognate 1, Non-Cognate -1).

When including Target Duration as a covariate in the model, the best fitting converging model justified by the data included the interaction between the two fixed effects, and the by-subject and by-item intercepts. Both analyses revealed a main effect of Relatedness, $z>5.30, p<.001$, indicating that semantic priming facilitates comprehension in second language word recognition accuracy in babble noise. In the first analysis, we observed a significant effect of Cognate Status, $\mathrm{z}=-3.09, p=.002$, as well as an interaction between Relatedness and Cognate status, $\mathrm{z}=2.38, p=.02$, demonstrating that semantic priming modulates crosslinguistic competition effects for cognates (see Table A in the Supplementary Materials for more details). In the finergrained analysis, the main effect of Cognate Type for the Identical-Cognates vs. NonCognates contrast was significant, $\mathrm{z}=-2.39, p=.02$. Including the interaction between Type Of Cognate and Relatedness significantly improved the model fit. However, the interaction of Partial-Cognates vs. Non-Cognate and Relatedness did not reach significance, $\mathrm{z}=1.64, p=.1$.

Long-term priming Results. Table 3 presents the accuracy scores. The best fitting converging model using contrast effect codes for OldNew (New 1, Old -1) and for CognateStatus (Cognate 1, Non-Cognate -1) showed a significant effect of Old vs. New words, $\mathrm{z}=-3.42, p<.001$, and of Cognate Status, $\mathrm{z}=-2.6, p=.01$, and a significant interaction between these factors, $p=.02$. Thus, prior exposure increased later recognition accuracy, but only for the Cognates, $p<.001$. 
[Table 3]

Given the interaction between OldNew and Cognate status, separate analyses were conducted on New and Old words. For the analysis on the Old items, contrast effect codes were used for Relatedness (Related 1, Unrelated -1). For Old items, neither the main effect of Relatedness nor the interaction between Relatedness and Cognate Status reached significance $p>.1$, and the main effect of Cognate Status only showed a trend, $\mathrm{z}=-1.74, p=.08$. For New items, the effect of Cognate Status was significant, $\mathrm{z}=-$ $2.69, p=.007$ (5.9\% difference in accuracy), replicating the lower accuracy found for Cognates in the initial lexical decision task.

\subsection{Experiment 1 Discussion}

Experiment 1 examined the effects of semantic priming and phonological cognate status on lexical decision for L2 targets presented in babble noise. As predicted, phonological cognate status affected word recognition accuracy in noise. Notably, the effect was inhibitory. Finding a negative effect of cognate status is somewhat unusual, but not unprecedented. Temnikova and Nagel's (2015) study of Russian-English bilinguals shares some features with our study (although items were presented in the clear) and found similar results. As in the current study, there was an inhibitory main effect of cognate status. Both studies, which used similar paradigms, suggest that auditory word recognition of L2 targets is slower (and in this case, also less accurate) when targets share phonological-lexical form with an L1 word.

As predicted, semantic priming significantly increased accuracy of second language word recognition in noise. Critically, this effect was modulated by phonological cognate status, reflected in the Relatedness $\times$ Cognate Status interaction. 
This finding suggests that crosslinguistic phonological-lexical "lateral" interactions and lexical-semantic "hierarchical" interactions can affect one another. This interaction is due to a relative decreased recall for phonological Cognates preceded by an unrelated prime compared to Non-Cognates. It appears that as crosslinguistic interaction increases due to increased phono-lexical overlap, so does lexical competition (perhaps due to increased language co-activation increasing the pool of potential lexical candidates that are competing with one another). However, this decreased word recognition accuracy disappears when a semantically related prime precedes the target. Overall, semantic priming seems to offer a way to overcome the word recognition costs incurred by increased competition effects with an unrelated prime due to language co-activation (induced by crosslinguistic phonological-lexical overlap), in noisy listening conditions. Speculating on this finding, semantic priming may enhance the activation of the semantic network comprising the target word. In addition, it may help facilitate the detection of errors that result from an incorrect sound to lexical mapping, helping to suppress activation of competing items, thereby improving word recognition accuracy.

The long term priming task showed that Old items were more accurately recognized than New items, replicating prior work on repetition priming effects during a lexical decision task (e.g., Bowers et al., 2000). It also provides some support for the interpretation that lexical activation may have been modulated by Cognate Status. As predicted, the Old vs. New repetition effect was modulated by phonological Cognate Status. It is also possible that prior lexical activation, more generally, provided sufficient support to overcome the negative effect of Cognate Status.

The repetition effect found for Cognates suggests that their activation may be higher due to crosslinguistic interactions during the initial lexical decision test. In contrast, New items did not show a difference between Cognates and Non-Cognate. 
Instead, performance was impaired as before (presumably due to lexical-lexical competition, exacerbated by the uncertainty under noisy listening conditions).

\section{Experiment 2}

Experiment 1 showed that under noisy listening conditions, crosslinguistic interactions can modulate semantic priming effects on word recognition accuracy. The clear listening conditions of Experiment 2 allow for accurate lexical access. Therefore, effects of crosslinguistic and semantic priming will be measured as a function of changes in processing speed rather than accuracy (which should be near ceiling in the clear).

\subsection{Methods}

Stimuli. Stimuli were the same as in Experiment 1, but without babble noise.

Participants. 20 early proficient (L1-L2) Spanish-Basque bilinguals participated (17 female; mean age $=24.2, \mathrm{SD}=4.3 ;$ mean age of Basque acquisition $=2.3, \mathrm{SD}=0.5$; mean BEST Basque picture-naming score $=53.4$, SD 5.6). None had participated in Experiment 1. To better understand the profile of the bilinguals in the current study, and the potential generalizability of the results, we provide additional information about percentages of self-assessed language exposure and proficiency, taken from the BCBL database (Participa). including mean \% L1 (Spanish) Exposure $=58, \mathrm{SD}=17$, Speaking $=64, \mathrm{SD}=13$, Hearing $=56, \mathrm{SD}=18$, Reading $=53, \mathrm{SD}=24, \% \mathrm{~L} 2$ (Basque) Exposure $=29, \mathrm{SD}=17$, Speaking $=27, \mathrm{SD}=11$, Hearing $=27, \mathrm{SD}=15$, Reading $=31, \mathrm{SD}=24$, 
$\%$ Bilingual Language Context $=49, \mathrm{SD}=24$, and Interview Mark in Basque assessed by research assistant $(\max$ score 5$)=4.45, \mathrm{SD}=0.51$.

\section{Procedure.}

The procedure was the same as in Experiment 1.

\subsection{Results}

Table 2 presents the accuracy and reaction time results. As expected, accuracy was near ceiling ( $95 \%$ overall). Thus, as planned, we focus on processing speed. We use the same statistical procedure as in Experiment 1 but this time with reaction time (for correct responses) as the dependent measure in a linear mixed effects model (implemented in $\mathrm{R}$ with lmer in the lme4 package). Figure 2 shows the reaction time results, broken down by condition.

With Target Length as a covariate in the model, the best-fitting converging model justified by the data included each fixed effect (Cognate vs Non-Cognate, and Related vs Unrelated primes), by-subject random slopes of cognate status, and by-item and bysubject random intercepts (see Table B in Supplementary Materials for detailed results). There was a significant effect of Relatedness, $t=-4.49, p<.001$, and Cognate Status, $t$ $=2.63, p=.01$. As can be seen in Table 2, and in Figure 2, responses to Cognates were again slower than responses to Non-Cognates. This slower processing speed was not modulated by providing a within-language semantic prime. The fine-grained analyses show a main effect of Relatedness, $\mathrm{t}=-4.52, p<.001$, and of Cognate Contrast Type 2 (Identical-Cognate vs. Non-Cognate), $t=2.59, p=.02$. Including the interaction between Relatedness and Cognate Type did not improve the model fit, and for the model that did include it, it was not significant, $\mathrm{p}>.1$. 
[Figure 2]

Long Term Priming Test. Table 3 shows the reaction time results for the long term priming test. Reaction times were generally longer for Cognates than for Non-Cognates, and longer for New items than for Old items. The best fitting converging model revealed a significant effect of Old vs. New items, $t=10.2, p<.001$, but no effect of Cognate Status, $t=0.84, p=0.4$. For New items, responses to Cognates were slower (by $53 \mathrm{~ms}$ ) than Non-Cognates. However, the effect of Cognate status did not reach significance, (Cognate Status, $t=0.59, p=0.55$ ), and there were no other significant main effects (other than the target duration covariate) or interactions reaching significance. No significant effects were found in an analysis examining differences among the Old items.

\subsection{Experiment 2 Discussion}

Degrading the speech signal (e.g., via babble noise) challenges the perceptual system enough to reveal aspects of the underlying processes or functional organization that may normally proceed too effectively to observe an effect. In Experiment 1, this approach demonstrated effects of crosslinguistic phonological similarity, semantic priming, and their interaction, on word recognition accuracy. Perhaps surprisingly, even in the clear listening conditions of Experiment 2, we were able to observe an effect of crosslinguistic interactions and semantic priming on word recognition processing speed, consistent with the report by Temnikova and Nagel (2015). Semantic priming shortened response times, whereas the existence of a matching crosslinguistic word (i.e., a cognate) slowed response times. Unlike the effects on accuracy observed in Experiment 
1's noisy listening conditions, there was no significant interaction between semantic priming and phonological cognate status on reaction times, which is again consistent with the Temnikova and Nagel (2015) study (that was also conducted in clear listening conditions; even in the noisy conditions of Experiment 1, the reaction time pattern was qualitatively consistent with that found here).

\section{General Discussion}

Spoken language comprehension involves the identification of specific sound sequences that map onto an associated meaning. Bilingualism presents a case in which two words with identical, similar, or different phonological sequences can map onto a common meaning. The current study sought to elucidate how the bilingual spoken word recognition system copes with multiple, language-specific sound-to-meaning maps, across two language systems during second language processing. In particular, we examined whether the functional organization of the second language interacted with that of the native language at the phonological and lexical-semantic levels during auditory word recognition, in a purely second language experimental context. Moreover, we were interested in whether this potential interaction had consequences for the flexible processes that allow spoken word recognition to accommodate adverse listening conditions (in this case mediated by meaning).

To gain insight into this question, we investigated how the phonological overlap of L2 words with their translation equivalents, and semantic relationships to a preceding within-language prime, affect spoken word recognition under noisy (Experiment 1) and quiet (Experiment 2) listening conditions. Collectively, the results of Experiments 1 and 2 show that these highly proficient/early (L1-Spanish, L2-Basque) bilinguals benefit 
from semantic priming on measures of word recognition accuracy (in noise), and on processing speed (in quiet). Both experiments also show that the presence of a phonological cognate in the native language, overall, leads to inhibitory effects on auditory word recognition performance (slower reaction time and lower accuracy), especially when preceded by an Unrelated prime. Moreover, in noisy listening conditions (Experiment 1), a significant interaction between phonological cognate status and semantic priming on accuracy was found; semantic priming was greater for Cognates compared to Non-Cognates, a large enough difference to overcome the inhibitory effect in the unrelated prime condition. This interaction was not significant on the response times in quiet listening conditions (Experiment 2).

\section{Semantic Priming}

The facilitation produced by semantic priming suggests that when there is uncertainty produced by noise, second language processing by early/proficient bilinguals is flexible enough to make use of a constraining semantic context, boosting second language word recognition accuracy. This finding is consistent with other studies conducted in proficient bilinguals' second language (Kousaie el al, 2019 Temnikova et al., 2015), and contrasts with the null effects of semantic priming previously found for non-proficient bilinguals' second language (Golestani, 2009) and other null effects of context (e.g., lexical context) for non-proficient compared to proficient bilinguals (Samuel \& Frost, 2015). Thus, flexible perception may depend on the strength of the associations between L2 sounds and meaning, and/or L2 words and L1 words, which is presumed to be greater for proficient compared to non-proficient bilinguals. Recent neuroimaging work provides supporting evidence for this interpretation. Just as native listening shows better neural entrainment for more 
intelligible speech (Peelle, Gross, and Davis, 2013), there are also differences in neural entrainment between native and non-native listeners; specifically, poorer entrainment has been associated with the degree to which comprehension is impaired by noise in non-native listeners, at levels of processing that go beyond the syllable level (BlancoElorrieta, 2019).

\section{Phonological Cognate Status}

The results showing effects of phonological cognate status provide good evidence for crosslinguistic phonological-lexical interactions, induced merely by overlap with native phonological-lexical forms, even when the experimental language context was carefully designed to only involve the second language. These interactions were prominent when listening conditions were challenging. Although it may seem unusual, the reduced accuracy and slowed response times associated with phonological cognate status found in the current study are not surprising when taken in the context of the broader literature on bilingualism and second language processing. Many studies have shown a reduction, elimination, or reversal of cognate facilitation with task, language, and stimulus manipulations. Dijkstra et al. (2014) showed inhibitory effects of cognate status that depended on a semantic context manipulation. Specifically, they found that (1) low constraining sentences produced an inhibitory effect on L1 cognates and (2) when the sentence context was in L2, inhibitory effects were also found for high constraining sentences. As noted above, Temnikova and Nagel (2015) showed inhibitory effects of cognate status under conditions like those tested in Experiment 2 here.

Effects of cognate status (be they inhibition or facilitation) provide evidence for the activation of the non-target language. In speech production, inhibitory effects of 
cognate status have also been reported when proficient bilinguals are naming pictures in L2, which have been attributed to increased competition at the lexical-semantic level (e.g., Broersma, Carter, \& Acheson, 2016). Even in cases where cognate effects lead to facilitation of L2 production, the co-activation of a non-target native language seems to be associated with increased lexical competition. For example, Acheson et al. (2012) observed evidence for greater conflict monitoring processes (a larger Event Related Negativity), despite facilitation for cognates compared to non-cognates on a naming task. This effect was attributed to increased competition from the multiple activated potential outputs of cognates compared to non-cognates and increased need for conflict monitoring. The observed interaction in the current study, between phonological cognate status and the semantic priming manipulation found in babble noise (Experiment 1), may guide the interpretation of how the co-activation of multiple representations can affect lexical dynamics, and bears on the functional organization of bilingualism and second language processing.

\section{Semantic Priming $\times$ Phonological Cognate Status Interaction in Noise}

In the babble noise condition, reduced accuracy was found for phonological cognates when the target was preceded by an unrelated prime but not when it was preceded by a related prime. Because noise introduces a high degree of uncertainty in the perceptual mapping of the acoustic speech signal, alternative mappings must be considered/maintained before settling on the candidate that best fits the mutual constraints of the available information (Scharenborg \& van Os, 2019). Following an unrelated prime, lexical-semantic competitors are more likely to be co-activated as the target word is presented, thereby increasing the number of potentially competing lexical candidates. If, in parallel, crosslinguistic phonological-lexical overlap promotes co- 
activation of the other "non-target" language network (which in this case is native and may thus dominate the target language, see Weber \& Cutler, 2004), competition effects will be exacerbated by an even larger pool of candidates, potentially reducing the accuracy in mapping the acoustic speech signal. This interpretation is consistent with a study by Blumenfeld and Marian (2005), which provides evidence that cognates are more likely to co-activate competing cohort items from both languages than noncognates. In contrast, following a related semantic prime, there should be less lexical competition. Specifically, as the perceptual mapping evolves, co-activated cognate lexical forms will not only converge onto the same meaning, but will also support (at least partially) the same perceptual mapping, which will help to suppress competitors. In addition, enhanced activation of the target's lexical form may help facilitate error detection of incorrectly activated phonological information, facilitating accurate word recognition.

Enhanced lexical activation and competitor suppression may be achieved through a number of possible mechanisms. According to some models of bilingualism (e.g., BIA+, Dijkstra \& van Heuven, 2002), connections between orthographic, phonological, and semantic representations are interactive and bidirectional, causing similar lexical forms across two languages to resonate with one another through their shared phonology and meaning (Thomas \& van Heuven, 2005; van Heuven, 2005). Presumably, such resonance among different codes (processes) increases a word's level of activation. Even in other models that may not share the same structure as BIA+, enhanced levels of activation can still emerge from the learned associations across levels of processing and across languages (Hernandez, Li, \& MacWhinney, 2005; Kroll et al., 2010; Li \& Farkas, 2002; Shook \& Marian, 2013; Thomas \& van Heuven, 2005; van Heuven, 2005). Of course, the consequences of this semantically-mediated 
phonological-lexical boost will be subject to the specific functional architecture of a given model. For example, if semantic information is not shared across languages in the model, semantic priming effects cannot directly enhance activation of both lexical forms, but can do so indirectly through excitatory interactions between shared lexical forms at the lexical level. All of these factors would then interact with the bilingual's level of proficiency (for a review on potential interactions between L2 proficiency and interference control, see Kim, Marton, and Obler, 2019).

\section{Insights from monolingual spoken word recognition}

The complex cascading effects of noisy listening conditions and phonologicallexical interactions on lexical dynamics are not unique to bilingualism. A number of studies conducted with native language listeners have manipulated the phonologicallexical properties of targets under difficult listening conditions and may offer some additional insight into the interpretation of the results. For example, embedded words have been used as a within-language manipulation of phonological-lexical overlap, under better or worse listening conditions. For embedded words, the sequence of sounds that form part of the "carrier" word (e.g., "trombone") is also consistent with a shorter word (e.g., "bone") that maps onto a different meaning. Using either the carrier word as a prime for the embedded word or the embedded word as a prime for the carrier word, Zhang and Samuel (2015) replicated the finding that under optimal listening conditions, carrier words activate embedded words (and vice versa) and their meaning (MarslenWilson et al., 1994; Vroomen and de Gelder, 1997; Salverda, Dahan, and McQueen, 2003; Bowers et al., 2009). However, this priming effect was eliminated when the signal was degraded, or was presented under cognitive load. To account for the null effect under the degraded and cognitive load conditions, the authors proposed two 
possible mechanisms: degradation/load could either impede lexical access of the competing items, or it could tax cognitive processes needed to keep competitors active, thereby eliminating effects due to lexical competition. In a follow-up study, Zhang and Samuel (2018) manipulated different types of cognitive load to tease apart these possibilities and found that cognitive load affects lexical competition, not initial lexical access. Under difficult conditions, they suggest that listeners engage in "tunnel" listening, limiting the number of competitors kept active, consistent with models such as the Ease of Language Understanding hypothesis (Rönnberg et al., 2013).

Phonological-lexical manipulations such as phonological neighborhood density have also been examined in quiet versus noisy listening conditions. In denser phonological neighborhoods, the increased number of similar sounding words produces greater competition and greater inhibition of the target word. Noise seems to produce a larger inhibitory effect of neighborhood density, suggesting that increased uncertainty in the perceptual mapping causes greater lexical competition for larger phonological neighborhoods. However, this inhibitory effect interacts with other lexical factors; specifically, neighborhood density effects were mitigated by words of higher frequency, in noise more than in the clear (Taler, Steinmetz, \& Pisoni, 2010). Other studies showed similar effects of noise, with more challenging listening conditions increasing competition effects due to neighbors with phonological-orthographic overlap (Chiarello, Vaden, \& Eckert, 2018). Phonological neighborhood manipulations also induce crosslinguistic effects; a word presented in the target language is sensitive to the size of the other (non-target) language's phonological neighborhood size (van Heuven, Dijkstra, \& Grainger, 1998), providing additional evidence for phonologically-induced language co-activation of the non-target language. Taken together, the evidence indicates that competition effects during word recognition may be provoked both by 
crosslinguistic phonological-lexical overlap and noise. There is evidence that noise on onset (versus word-final) differentially affects recognition, suggesting that onsets may be more important (Coumans et al., 2014). Most of the partial cognates used in the current study overlapped in the onset consonant; it would be interesting to see if similar effects would be found for overlap in different positions.

It is important to note a key difference between cognates and the other phonological-lexical overlap manipulations: Cognates map onto the same meaning, across the two languages, whereas the within-language manipulations (above) involve words that map onto different (competing) meanings. The shared meaning and phonology for cognates may automatically activate the non-target language and potentially competing lexical candidates. Thus, in the absence of a constraining context, there will be more competition for cognates compared to non-cognates as the system settles on the best mapping of the speech signal. Semantic priming may narrow the possibilities to those that are within the prime's semantic network and inhibit other phonological competitors. Consistent with this interpretation, Chen and Mirman (2015) showed that even inhibitory effects due to phonological neighbor competition are reduced by semantic priming. Their interactive model predicts that effects of phonological neighbors should increase with increased activation of phonological information (in this case neighbors are inhibitory), but that the effect can be reversed when there is increased activation of semantic information, resulting in facilitation.

Perhaps, as cognitive noise/load reduces the competition effects of semantically unrelated embedded words (and frequency and semantic context reduce competition effects due to neighborhood density in noise), so can semantic priming reduce the competition effects of semantically unrelated competitors activated by crosslinguistic interactions, in noise, facilitating accurate word recognition. Accordingly, the 
constraints provided by semantic priming may offer a means to achieve "tunnel" listening, in noise. Reliance on context (be it lexical or semantic) increases under conditions that require flexibility (e.g., noise, cognitive load), but the ability to use such information (and perceive spoken language flexibly) is affected by the presence of other competing sources of information (e.g., semantically unrelated competitors).

\section{Long-term priming}

The long-term priming findings show the expected repetition effect of previously heard items. However, in Experiment 1, the Cognates and Non-Cognates produced somewhat different patterns. For the Non-Cognates, performance on the final lexical decision task was essentially flat across Old-Related, Old-Unrelated, and New items. For the Cognates, performance was highest for the Old-Related, followed by the Old-Unrelated, and then by the New items. Thus, the observed inhibitory effect of phonological cognate status on word recognition during the initial test is not likely due to a lack of, or weaker, lexical access/activation for cognates. Rather, it seems to reflect other processes such as lexical competition. Such competition is likely to increase following an unrelated prime due to the activation of additional lexical competitors. It might also be the case that the repetition effect associated with a previously heard word outweighs any reduced accuracy due to crosslinguistic competition. Interestingly, a recent paper shows that noise may have different effects, in different tasks; despite a disadvantage for bilinguals compared to monolinguals on word recognition in noise, none is found for word learning (Morini and Newman, 2019). This pattern suggests that competition effects can indeed be overridden through repetition and learning.

\section{Conclusion}


Taken together, the results of Experiments 1 and 2 suggest that crosslinguistic phonological-lexical-semantic overlap promotes L1 activation, increasing lexical competition, in the presence of a semantically unrelated prime (or in isolation) and noise. However, semantic priming can compensate for the inhibitory effect of a phonological cognate when target items are presented in noise. This semantic support thus seems to reinforce the activation of a target by suppressing competition.

The long-term priming results show that phonological cognates (in languages with large phonological overlap) may have a greater repetition effect than non-cognates. This finding supports the interpretation that target items were indeed activated during the initial presentation. The observed effects are, therefore, most likely due to 1) a repetition effect that outweighs any competition effects, and/or 2) the result of prior competition induced by the crosslinguistic interaction.

In summary, the current study demonstrates that second language auditory word recognition can be modulated by crosslinguistic phonological-lexical-semantic overlap. Models of spoken word recognition suggest that correct mapping of the speech signal depends on the interplay of many factors such as signal quality, context, listeners' experiences, and more general cognitive processes. The current study suggests that the functional architecture of a model of bilingual auditory word recognition - at least, for early/proficient bilinguals - should also take the potential impact of cross-linguistic interactions on this interplay into account.

With respect to the specific results of the current study, it is important that they be interpreted within the full context of the experimental manipulations, specific language pair, bilingual population and language environment. First, the primary task in this study is a semantic priming paradigm where targets were preceded by related or unrelated primes, in the auditory modality. Second, the language pair consists of highly 
overlapping phonologies (perhaps more than other commonly used language pairs in previously published word recognition studies). Third, the bilingual population consists of early proficient bilinguals, who learned Basque (L2) after Spanish (L1). Fourth, the language environment where the study was conducted is an official bilingual community where listeners commonly access both languages for daily activities (i.e. both languages are used in stores, on street signs, in the media). Finally, we also note that while our sample size was sufficient to obtain a good number of statistically reliable effects, it would be interesting to see whether some effects that were not reliable here might be detectable with a larger sample. 


\section{References}

Acheson, D. J., Ganushchak, L. Y., Christoffels, I. K., \& Hagoort, P. (2012). Conflict monitoring in speech production: physiological evidence from bilingual picture naming. Brain and language, 123(2), 131-136.

Barroso, N., de Ipiña, K. L., \& Ezeiza, A. (2010). Acoustic Phonetic Decoding Oriented to Multilingual Speech Recognition in the Basque Context. In Trends in Practical Applications of Agents and Multiagent Systems (pp. 697-704). Springer, Berlin, Heidelberg.

Blanco-Elorrieta, E., Ding, N., Pylkkänen, L., \& Poeppel, D. (2019). Understanding requires tracking: noise and knowledge interact in bilingual comprehension. bioRxiv, 609628.

Blumenfeld, H. K., Bobb, S. C., \& Marian, V. (2016). The role of language proficiency, cognate status and word frequency in the assessment of Spanish-English bilinguals' verbal fluency. International journal of speech-language pathology, $18(2), 190-201$.

Blumenfeld, H. K., \& Marian, V. (2005). Covert bilingual language activation through cognate word processing: An eye-tracking study. Paper presented at the Proceedings of the Annual Meeting of the Cognitive Science Society.

Bowers, J. S., Davis, C. J., Mattys, S. L., Damian, M. F., \& Hanley, D. (2009). The activation of embedded words in spoken word identification is robust but constrained: Evidence from the picture-word interference paradigm. Journal of Experimental Psychology: Human Perception and Performance, 35(5), 1585.

Broersma, M., Carter, D., \& Acheson, D. J. (2016). Cognate costs in bilingual speech production: Evidence from language switching. Frontiers in psychology, 7, 1461. 
Bultena, S., Dijkstra, T., \& van Hell, J. G. (2014). Cognate effects in sentence context depend on word class, L2 proficiency, and task. The Quarterly Journal of Experimental Psychology, 67(6), 1214-1241.

Caramazza, A., \& Brones, I. (1979). Lexical access in bilinguals. Bulletin of the Psychonomic Society, 13(4), 212-214.

Chiarello, C., Vaden Jr, K. I., \& Eckert, M. A. (2018). Orthographic influence on spoken word identification: Behavioral and fMRI evidence. Neuropsychologia, $111,103-111$.

Chen, Q., \& Mirman, D. (2015). Interaction between phonological and semantic representations: Time matters. Cognitive Science, 39, 538-555. doi: $10.1111 / \operatorname{cogs} .12156$

Costa, A., Caramazza, A., \& Sebastian-Galles, N. (2000). The cognate facilitation effect: implications for models of lexical access. Journal of Experimental Psychology: Learning, Memory, and Cognition, 26(5), 1283.

Coumans, J., Hout, R. V., \& Scharenborg, O. (2014). Non-native word recognition in noise: The role of word-initial and word-final information. In Fifteenth Annual Conference of the International Speech Communication Association.

Cutler, A., Weber, A., Smits, R., \& Cooper, N. (2004). Patterns of English phoneme confusions by native and non-native listeners. The Journal of the Acoustical Society of America, 116(6), 3668-3678.

Cutler, A. (2005) Why is it so hard to understand a second language in noise?. Newsletter, American Association of Teachers of Slavic and East European Languages, 48, 16-16

de Bruin, A., Carreiras, M., \& Duñabeitia, J. A. (2017). The BEST dataset of language proficiency. Frontiers in psychology, 8, 522. 
Dijkstra, T. (2007). The multilingual lexicon. psycholinguistics, 251-265.

Dijkstra, T., van Hell, J. G., \& Brenders, P. (2015). Sentence context effects in bilingual word recognition: Cognate status, sentence language, and semantic constraint. Bilingualism: Language and Cognition, 18(4), 594-613.

Dijkstra, T., \& van Heuven, W. J. B. (2002). The architecture of the bilingual word recognition system: From identification to decision. Bilingualism: Language and Cognition, 5(3), 175-197. doi: 10.1017/S1366728902003012

Dijkstra, T., Wahl, A., Buytenhuijs, F., Van Halem, N., Al-Jibouri, Z., De Korte, M., \& Rekké, S. (2018). Multilink: a computational model for bilingual word recognition and word translation. Bilingualism: Language and Cognition, 1-23.

Duñabeitia, J.A., Casaponsa, A., Dimitropoulou, M., Martí, A., Larraza, S., \& Carreiras, M. (In preparation). BaSp: A Basque-Spanish database of translation equivalents.

Duyck, W., Van Assche, E., Drieghe, D., \& Hartsuiker, R. J. (2007). Visual word recognition by bilinguals in a sentence context: evidence for nonselective lexical access. Journal of Experimental Psychology: Learning, Memory, and Cognition, $33(4)$.

Golestani, N., Rosen, S., \& Scott, S. K. . (2009). Native-language benefit for understanding speech-in-noise: The contribution of semantics. . Bilingualism: Language and Cognition,, 12(3), 385-392.

Gollan, T. H., Forster, K. I., \& Frost, R. (1997). Translation priming with different scripts: Masked priming with cognates and noncognates in Hebrew-English bilinguals. Journal of Experimental Psychology: Learning, Memory, and Cognition, 23(5), 1122. 
Hernandez, A., Li, P., \& MacWhinney, B. (2005). The emergence of competing modules in bilingualism. Trends in cognitive sciences, 9(5), 220-225.

Hervais-Adelman, A., Pefkou, M., \& Golestani, N. (2014). Bilingual speech-in-noise: Neural bases of semantic context use in the native language. Brain and language, 132, , 1-6.

Kalikow, D. N., Stevens, K. N., \& Elliott, L. L. (1977). Development of a test of speech intelligibility in noise using sentence materials with controlled word predictability. The Journal of the Acoustical Society of America, 61(5), 13371351.

Kim, J., Marton, K., \& Obler, L. (2019). Interference control in bilingual auditory sentence processing in noise. In I. Sekerina, L. Sradlin \& V. Valina (Eds.), Bilingualism, Executive Function, and Beyond: Questions and insights (pp. 103116): John Benjamins Publishing Company.

Kousaie, S., Baum, S., Phillips, N. A., Gracco, V., Titone, D., Chen, J. K., ... \& Klein, D. (2019). Language learning experience and mastering the challenges of perceiving speech in noise. Brain and language, 196, 104645.

Krizman, J., Bradlow, A. R., Lam, S. S. Y., \& Kraus, N. (2017). How bilinguals listen in noise: linguistic and non-linguistic factors. Bilingualism: Language and Cognition, 20(4), 834-843.

Kroll, J. F., van Hell, J. G., Tokowicz, N., \& Green, D. W. (2010). The Revised Hierarchical Model: A critical review and assessment. . Bilingualism: Language and Cognition, 13(3), 373-381.

Larraza, S., Samuel, A. G., \& Oñederra, M. L. (2016). Listening to accented speech in a second language: First language and age of acquisition effects. Journal of Experimental Psychology: Learning, Memory, and Cognition, 42(11), 1774. 
Lemhölfer, K., \& Dijkstra, T. (2004). Recognizing cognates and interlingual homographs: Effects of code similarity in language-specific and generalized lexical decision. Memory \& Cognition, 32, 533-550.

Li, P., \& Farkas, I. (2002). Bilingual Processing. Bilingual sentence processing, 134, 59.

Marslen-Wilson, W., Tyler, L. K., Waksler, R., \& Older, L. (1994). Morphology and meaning in the English mental lexicon. Psychological review, 101(1), 3.

Morini, G., \& Newman, R. S. (2019). Monolingual and Bilingual Word Recognition and Word Learning in Background Noise. Language and speech, 0023830919846158.Peeters, D., Dijkstra, T., \& Grainger, J. (2013). The representation and processing of identical cognates by late bilinguals: RT and ERP effects. Journal of memory and language, 68(4), 315-332.

Perea, M., Duñabeitia, J. A., \& Carreiras, M. (2008). Masked associative/semantic and identity priming effects across languages with highly proficient bilinguals. Journal of memory and language, 58, 916-930.

Poort, E. D., \& Rodd, J. M. (2017). The cognate facilitation effect in bilingual lexical decision is influenced by stimulus list composition. Acta Psychologica, 52-63.

Reetzke, R., Lam, B. P. W., Xie, Z., , Sheng, L., \& Chandrasekaran, B. (2016). Effect of Simultaneous Bilingualism on Speech Intelligibility across Different Masker Types, Modalities, and Signal-to-Noise Ratios in School-Age Children., . PloS one, 11(12), e0168048.

Rönnberg, J., Lunner, T., Zekveld, A., Sörqvist, P., Danielsson, H., Lyxell, B., . . . Pichora-Fuller, M. K. (2013). The Ease of Language Understanding (ELU) model: theoretical, empirical, and clinical advances. Frontiers in systems neuroscience, 7,31 . 
Salverda, A. P., Dahan, D., \& McQueen, J. M. (2003). The role of prosodic boundaries in the resolution of lexical embedding in speech comprehension. Cognition, 90(1), 51-89.

Samuel, A. G., \& Frost, R. (2015). Lexical support for phonetic perception during nonnative spoken word recognition. Psychonomic Bulletin \& Review, 22(6), $1746-1752$.

Sheng, L., Lam, B. P. W., Cruz, D., \& Fulton, A. (2016). A robust demonstration of the cognate facilitation effect in first-language and second-language naming. Journal of experimental child psychology, 141, 229-238.

Shi, L. F. (2012). Contribution of linguistic variables to bilingual listeners' perception of degraded English sentences. Journal of Speech, Language, and Hearing Research, 55(1), 219-234.

Shi, L. F. (2014). Measuring effectiveness of semantic cues in degraded English sentences in non-native listeners. International journal of audiology, 53(1), 3039.

Shi, L. F. (2015). How "Proficient” Is Proficient? Bilingual Listeners' Recognition of English Words in Noise. American journal of audiology, 24(1), 53-65.

Shook, A., \& Marian, V. (2013). The bilingual language interaction network for comprehension of speech. Bilingualism: Language and Cognition, 16(2), 304324. doi: 10.1017/S1366728912000466

Scharenborg, O., \& van Os, M. (2019). Why listening in background noise is harder in a non-native language than in a native language: A review. Speech Communication.

Schmidtke, J. (2016). The bilingual disadvantage in speech understanding in noise is likely a frequency effect related to reduced language exposure. Frontiers in Psychology, 7, 678. 
Sumby, W. H., \& Pollack, I. (1954). Visual contribution to speech intelligibility in noise. The Journal of the Acoustical Society of America, 26(2), 212-215.

Tabri, D., Chacra, K. M. S. A., \& Pring, T. (2015). Speech perception in noise by monolingual, bilingual and trilingual listeners. International Journal of Language \& Communication Disorders, 1-12.

Taler, V., Aaron, G. P., Steinmetz, L. G., \& Pisoni, D. B. (2010). Lexical neighborhood density effects on spoken word recognition and production in healthy aging. Journals of Gerontology Series B: Psychological Sciences and Social Sciences, $65(5), 551-560$.

Temnikova, I. G., \& Nagel, O. V. (2015). Effects of cognate and relatedness status on word recognition in Russian-English bilinguals of upper-intermediate and advanced levels Procedia-Social and Behavioral Sciences (Vol. 200, pp. 381386). The XXVI Annual Interantional Academic Conference, Language and Culture, 27-30 October.

Thomas, M. S., \& van Heuven, W. J. (2005). Computational models of bilingual comprehension. Handbook of bilingualism: Psycholinguistic approaches, 202225.

van Hell, J. G., \& de Groot, A. M. (2008). Sentence context modulates visual word recognition and translation in bilinguals. Acta Psychologica, 128(3), 431-451.

van Hell, J. G., \& Dijkstra, T. (2002). Foreign language knowledge can influence native language performance in exclusively native contexts. Psychonomic Bulletin \& Review, 9(4), 780-789.

van Heuven, W. J. (2005). Bilingual interactive activation models of word recognition in a second language. Second language writing systems, 260-288. 
van Heuven, W. J., Dijkstra, T., \& Grainger, J. (1998). Orthographic neighborhood effects in bilingual word recognition. Journal of memory and language, 39(3), $458-483$.

Vroomen, J., \& De Gelder, B. (1997). Activation of embedded words in spoken word recognition. Journal of Experimental Psychology: Human Perception and Performance, 23(3), 710.

Weber, A., \& Cutler, A. (2004). Lexical competition in non-native spoken-word recognition. Journal of memory and language, 50(1), 1-25.

Zhang, X., \& Samuel, A. G. (2015). The activation of embedded words in spoken word recognition. Journal of memory and language, 79, 53-75.

Zhang, X., \& Samuel, A.G. (2018). Is speech recognition automatic? Lexical competition, but not initial lexical access, requires cognitive resources. Journal of Memory and Language, 100, 32-50. 


\section{Footnotes}

${ }^{1}$ The BEST is a picture-naming task in which participants are asked to name 65 pictures. It is a simple task that is at ceiling in Spanish but shows variability in Basque (providing an additional measure of proficiency) that is most relevant for a study like this one that uses lexical decision tasks. This measure correlates with other proficiency measures and is conducted at a separate time when participants sign up to be part of the Center's participant pool.

${ }^{2}$ The phonological cognate score was based on phoneme overlap, therefore, when the same letters are mapped onto different sounds across the two languages, they are scored as different; when different letters map onto the same phoneme they are scored as the same. For example, in Spanish, the pronunciation of the letter $[z]$ is $[\theta]$, whereas in Basque it is [s] (Larraza, Samuel, and Oñederra, 2016). In contrast, the letter [v] in Spanish is the same phoneme as the letter $[\mathrm{b}]$ in Basque and therefore, when shared between the target and the translation equivalent, these phonemes are computed as the same in the phonological cognate score (the same rule is applied for other shared phonemes, e.g, $[\mathrm{c}]$ and $[\mathrm{k}]$ ). For more information about phoneme differences between Spanish and Basque see Barroso, Ipiña, and Ezeiza, 2010.

${ }^{3}$ The babble-noise was constructed following the procedure used in Dole, Hoen, and Meunier (2012). Six speakers (three males, three females) were recorded in a soundproof room while reading passages of Basque newspapers. From these individual six recordings, silences of more than one second were removed. Fragments containing pronunciation errors or exaggerated prosody were also discarded. We then applied noise reduction to eliminate artifact interference for each of the six individual tracks, and, finally, mixed the tracks to create the 6-talker babble. 


\section{Figure Captions}

Figure 1. Percentage of correctly recognized words on lexical decision for different types of cognates in a Related (Solid Gray) compared to Unrelated (Striped Gray) semantic prime condition.

Figure 2. Reaction times in milliseconds (from target onset) for correct responses in the lexical decision task for different types of cognates in a Related (Solid Gray) compared to Unrelated (Striped Gray) semantic prime condition. Primes and targets were presented in the clear. 
Table 1. Example Stimuli and Related Primes. For full stimulus set, see Supplementary Materials. The English translation is provided in parentheses.

\begin{tabular}{|c|c|c|c|c|c|}
\hline $\begin{array}{l}\text { Phonological } \\
\text { Cognate Type }\end{array}$ & Target & & Spanish & Related P & me \\
\hline Identical-Cognate & $\begin{array}{l}\text { kanoa } \\
\text { tren } \\
\text { silueta }\end{array}$ & $\begin{array}{l}\text { (canoe) } \\
\text { (train) } \\
\text { (silhouette) }\end{array}$ & $\begin{array}{l}\text { canoa } \\
\text { tren } \\
\text { silueta }\end{array}$ & $\begin{array}{l}\text { arraun } \\
\text { geltoki } \\
\text { itzal }\end{array}$ & $\begin{array}{l}\text { (paddle) } \\
\text { (station) } \\
\text { (shade) }\end{array}$ \\
\hline Partial-Cognate & $\begin{array}{l}\text { zeta } \\
\text { plater } \\
\text { azentu }\end{array}$ & $\begin{array}{l}\text { (silk) } \\
\text { (dish) } \\
\text { (accent }\end{array}$ & $\begin{array}{l}\text { seda } \\
\text { plato } \\
\text { acento }\end{array}$ & $\begin{array}{l}\text { kotoi } \\
\text { jatetxe } \\
\text { hizkuntza }\end{array}$ & $\begin{array}{l}\text { (cotton) } \\
\text { (restaurant) } \\
\text { (language) }\end{array}$ \\
\hline Non-Cognate & $\begin{array}{l}\text { konketa } \\
\text { giltza } \\
\text { izter }\end{array}$ & $\begin{array}{l}\text { (sink) } \\
\text { (key) } \\
\text { (thigh) }\end{array}$ & $\begin{array}{l}\text { lavabo } \\
\text { llave } \\
\text { muslo }\end{array}$ & $\begin{array}{l}\text { komun } \\
\text { ate } \\
\text { oilasko }\end{array}$ & $\begin{array}{l}\text { (bathroom) } \\
\text { (door) } \\
\text { (chicken) }\end{array}$ \\
\hline
\end{tabular}


Table 2. Lexical decision word recognition average accuracy and average reaction times for correct Responses for Non-Cognate and Cognate Targets in Related and Unrelated semantic prime conditions for Experiments 1 and 2. Standard errors of the mean over subjects are in parentheses.

\begin{tabular}{|c|c|c|c|c|c|}
\hline \multirow[t]{2}{*}{ Experiment } & Cognate Status & \multicolumn{2}{|c|}{$\begin{array}{c}\text { Accuracy } \\
\text { Mean (SEM) }\end{array}$} & \multicolumn{2}{|c|}{$\begin{array}{l}\text { Reaction Time in ms } \\
\text { (Target Onset) } \\
\text { Mean (SEM) }\end{array}$} \\
\hline & Cognate & $\begin{array}{l}\text { Related } \\
71.2(3.2)\end{array}$ & $\begin{array}{l}\text { Unrelated } \\
56.4(3.3)\end{array}$ & $\begin{array}{c}\text { Related } \\
1613(50)\end{array}$ & $\begin{array}{c}\text { Unrelated } \\
1636(49)\end{array}$ \\
\hline $\operatorname{Exp} 1$ & Non-Cognate & $69.9(3.2)$ & $66.6(2.4)$ & $1523(37)$ & $1562(35)$ \\
\hline $\operatorname{Exp} 2$ & $\begin{array}{l}\text { Cognate } \\
\text { Non-Cognate }\end{array}$ & $\begin{array}{l}96.3(1.2) \\
96.6(0.6)\end{array}$ & $\begin{array}{l}93.0(1.3) \\
95.6(1.1)\end{array}$ & $\begin{array}{l}1323(40) \\
1220(35)\end{array}$ & $\begin{array}{l}1351(46) \\
1266(40)\end{array}$ \\
\hline
\end{tabular}


Table 3. Lexical decision word recognition average accuracy (Experiment 1) and reaction times (Target Onset) for correct Responses (Experiment 2) for New stimuli and for Old stimuli. "Related" and "Unrelated" refer to the prime that had been presented during the initial task (no primes were presented during the long term priming task). Standard errors of the mean over subjects are in parentheses.

\begin{tabular}{cllll}
\hline & & $\begin{array}{c}\text { Old Related } \\
\text { Mean (SEM) }\end{array}$ & $\begin{array}{l}\text { Old Unrelated } \\
\text { Mean (SEM) }\end{array}$ & New \\
\hline Exp 1 & Cognate & $71.3(3.4)$ & $66.4(2.9)$ & $61.6(2.6)$ \\
Accuracy & Non-Cognate & $68.6(3.2)$ & $68.99(2.71)$ & $67.5(2.8)$ \\
\hline $\begin{array}{c}\text { Exp 2 } \\
\text { Reaction Time ms } \\
\text { (Target onset) }\end{array}$ & Cognate & $1210(35)$ & $1197(39)$ & $1261(39)$ \\
\hline
\end{tabular}


Figure 1. Percentage of correctly recognized words on lexical decision for different types of cognates in a Related (Solid Gray) compared to Unrelated (Striped Gray) semantic prime condition.

$22 \times 14 \mathrm{~mm}(300 \times 300 \mathrm{DPI})$ 


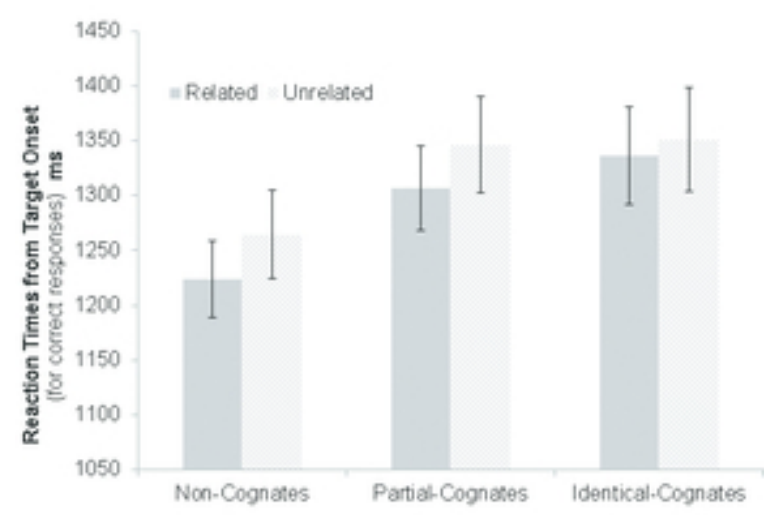

Figure 2. Reaction times in milliseconds (from target onset) for correct responses in the lexical decision task for different types of cognates in a Related (Solid Gray) compared to Unrelated (Striped Gray) semantic prime condition. Primes and targets were presented in the clear.

$24 \times 17 \mathrm{~mm}(300 \times 300 \mathrm{DPI})$ 


\section{Supplementary Materials}

List of Target Words and their Related Primes ${ }^{1}$

\begin{tabular}{|c|c|c|c|c|}
\hline CognateType & $\begin{array}{c}\text { Related } \\
\text { Prime }\end{array}$ & $\begin{array}{c}\text { Spanish } \\
\text { Translation }\end{array}$ & Target & $\begin{array}{c}\text { Spanish } \\
\text { Translation } \\
\end{array}$ \\
\hline Non-Cognate & $\begin{array}{c}\text { oin } \\
\text { piperbeltz } \\
\text { belarritako } \\
\text { gaixo } \\
\text { kapel } \\
\text { ostiko } \\
\text { urte } \\
\text { zezen } \\
\text { eskumuturra } \\
\text { janari } \\
\text { balea } \\
\text { eguzkilore } \\
\text { arrano } \\
\text { egur } \\
\text { zira } \\
\text { zizare } \\
\text { laguntza } \\
\text { beltz } \\
\text { ikazkin } \\
\text { ezkontza } \\
\text { belarri } \\
\text { jakintasun } \\
\text { baserritar } \\
\text { tximista } \\
\text { aldagela } \\
\text { ukimen } \\
\text { garbiketa } \\
\text { hosto } \\
\text { aingura } \\
\text { hilabete } \\
\text { tresna } \\
\text { ate } \\
\text { gorri } \\
\text { garagardo } \\
\text { bikote } \\
\text { eraztun } \\
\text { aterki } \\
\text { kizkur } \\
\text { ibai } \\
\text { erabaki } \\
\text { aurrerapen } \\
\text { abizen }\end{array}$ & $\begin{array}{c}\text { pie } \\
\text { pimiento } \\
\text { pendientes } \\
\text { enfermo } \\
\text { sombrero } \\
\text { patada } \\
\text { años } \\
\text { toro } \\
\text { muñeca } \\
\text { comida } \\
\text { ballena } \\
\text { girasol } \\
\text { águila } \\
\text { madera } \\
\text { chubasquero } \\
\text { gusano } \\
\text { apoyo } \\
\text { negro } \\
\text { minero } \\
\text { boda } \\
\text { oreja } \\
\text { sabiduría } \\
\text { campesino } \\
\text { aligeramiento } \\
\text { vestuario } \\
\text { tacto } \\
\text { limpieza } \\
\text { hoja } \\
\text { ancla } \\
\text { meses } \\
\text { herramienta } \\
\text { puerta } \\
\text { rojo } \\
\text { cerveza } \\
\text { pareja } \\
\text { anillo } \\
\text { paraguas } \\
\text { rizo } \\
\text { río } \\
\text { decision } \\
\text { progreso } \\
\text { apellido }\end{array}$ & $\begin{array}{c}\text { dantza } \\
\text { gatz } \\
\text { zilar } \\
\text { sukar } \\
\text { galtza } \\
\text { jipoi } \\
\text { mende } \\
\text { adar } \\
\text { hatz } \\
\text { gose } \\
\text { izotz } \\
\text { olio } \\
\text { txori } \\
\text { makila } \\
\text { beroki } \\
\text { sagar } \\
\text { ezgai } \\
\text { ilun } \\
\text { ikatz } \\
\text { senar } \\
\text { hots } \\
\text { amona } \\
\text { azoka } \\
\text { ekaitz } \\
\text { biluz } \\
\text { usaimen } \\
\text { neskame } \\
\text { haize } \\
\text { itsasontzi } \\
\text { aste } \\
\text { labana } \\
\text { giltza } \\
\text { lotsa } \\
\text { mozkor } \\
\text { emazte } \\
\text { esku } \\
\text { euri } \\
\text { buru } \\
\text { emari } \\
\text { batzar } \\
\text { urrats } \\
\text { izen }\end{array}$ & $\begin{array}{c}\text { baile } \\
\text { sal } \\
\text { plata } \\
\text { fiebre } \\
\text { pantalones } \\
\text { paliza } \\
\text { siglo } \\
\text { rama } \\
\text { dedo } \\
\text { hambre } \\
\text { hielo } \\
\text { aceite } \\
\text { pajaro } \\
\text { bara } \\
\text { abrigo } \\
\text { manzana } \\
\text { incapaz } \\
\text { oscuro } \\
\text { carbón } \\
\text { marido } \\
\text { ruido } \\
\text { abuela } \\
\text { mercado } \\
\text { tormenta } \\
\text { desnudo } \\
\text { olfativo } \\
\text { sirvienta } \\
\text { viento } \\
\text { barco } \\
\text { semana } \\
\text { cuchillo } \\
\text { llave } \\
\text { vergüenza } \\
\text { borracho } \\
\text { esposa } \\
\text { mano } \\
\text { lluvia } \\
\text { cabeza } \\
\text { caudal } \\
\text { asamblea } \\
\text { paso } \\
\text { nombre }\end{array}$ \\
\hline
\end{tabular}

${ }^{1}$ Primes were randomized to create Unrelated Primes. In a few cases, the Related prime was randomly paired with its target and this error was not noted until after the experiment was run. These cases were relabeled accordingly in the analyses. 


\begin{tabular}{|c|c|c|c|}
\hline $\begin{array}{l}\text { berritsu } \\
\text { ospe }\end{array}$ & $\begin{array}{l}\text { hablador } \\
\text { fama }\end{array}$ & $\begin{array}{c}\text { isil } \\
\text { jelosia }\end{array}$ & $\begin{array}{l}\text { callado } \\
\text { celo }\end{array}$ \\
\hline letagin & colmillo & hortz & diente \\
\hline galtza & pantalones & aldaka & cadera \\
\hline izerdi & sudor & bero & calor \\
\hline arrautza & huevo & oilo & gallina \\
\hline udaberri & primavera & loratu & florecimient \\
\hline ezkata & escama & arrain & pescado \\
\hline malko & lágrima & $\min$ & dolor \\
\hline hilkutxa & ataud & hildako & fallecido \\
\hline ezti & miel & erle & abeja \\
\hline kokots & barbilla & aho & boca \\
\hline askatasun & libertad & gorroto & odio \\
\hline berandu & tarde & azken & último \\
\hline eskutitz & letras & zigilu & sello \\
\hline egarri & sediento & lehor & seco \\
\hline hondar & arena & maskor & concha \\
\hline ogi & pan & gari & trigo \\
\hline kopeta & frente & sudur & nariz \\
\hline baso & bosque & ehiza & caza \\
\hline eskuila & cepillo & orrazi & peine \\
\hline osaba & tio & iloba & sobrino \\
\hline komun & baño & konketa & lavabo \\
\hline barre & risa & txantxa & broma \\
\hline kutxa & caja & biltegi & almacén \\
\hline amets & soñar & neke & cansancio \\
\hline sabai & techo & harresi & pared \\
\hline suge & serpiente & pozoi & veneno \\
\hline idazketa & escritura & maisu & maestro \\
\hline tximinia & hogar & teilatu & techo \\
\hline urmael & estanque & igel & rana \\
\hline erantzun & respuesta & galdera & pregunta \\
\hline lehengusu & primo & seme & hijo \\
\hline ubeldura & moretón & ukabil & puño \\
\hline erre & asado & labe & horno \\
\hline irten & salida & sartu & entrar \\
\hline kazkabar & granizo & dardara & temblor \\
\hline aurpegi & cara & lepo & cuello \\
\hline sustrai & raíz & enbor & tronco \\
\hline xerra & trozo & hirugihar & tocino \\
\hline bizkar & espalda & sorbalda & hombro \\
\hline mingain & lengua & ezpain & labio \\
\hline soineko & vestido & gona & falda \\
\hline ohe & cama & gau & noche \\
\hline urduritasun & nerviosismo & zirrara & emocion \\
\hline zahar & viejo & hauts & polvo \\
\hline txar & malo & on & bueno \\
\hline zelai & campo & belar & hierba \\
\hline distira & brillo & garbi & limpio \\
\hline sardeska & horquillas & aizto & cuchillo \\
\hline
\end{tabular}




\begin{tabular}{|c|c|c|c|}
\hline urtebetetze & cumpleaños & adin & siglo \\
\hline belaun & rodilla & hanka & pierna \\
\hline arau & regla & jolas & juegos \\
\hline arreba & hermana & anaia & hermano \\
\hline zoriontasun & felicidad & gozamen & disfrute \\
\hline ezker & izquierda & eskuin & derecho \\
\hline aulki & silla & mahai & mesa \\
\hline soka & cuerda & putzu & pozo \\
\hline kandela & vela & nahi & deseo \\
\hline ekialde & este & mendebalde & oeste \\
\hline bilera & reunion & asteko & semanal \\
\hline luzera & longitud & iraupen & duración \\
\hline irakurketa & lectura & ulermen & compresion \\
\hline etorkizun & futuro & itxaropen & esperanza \\
\hline zabalera & anchura & neurri & medida \\
\hline isiltasun & silencio & bakarti & solitario \\
\hline igerileku & piscina & uda & verano \\
\hline begirada & mirada & ikusmen & vista \\
\hline txakur & perro & hozkada & bocado \\
\hline azeri & zorro & otso & lobo \\
\hline amuarrain & trucha & marrazo & tiburón \\
\hline oilasko & pollo & izter & muslo \\
\hline gurutze & cruzar & biribil & redondo \\
\hline aza & $\mathrm{col}$ & tipula & cebolla \\
\hline jaunartze & comunión & eliza & iglesia \\
\hline astigar & arce & belardi & prado \\
\hline eztarri & garganta & mihi & lengua \\
\hline eskularru & guantes & txano & gorro \\
\hline edalontzi & vaso & garden & transparente \\
\hline pago & haya & haritz & roble \\
\hline kondaira & leyenda & idazle & escritor \\
\hline eskubaloi & balonmano & kirol & deporte \\
\hline berogailu & calefacción & negu & invierno \\
\hline muxu & beso & masail & mejilla \\
\hline larru & cuero & ile & pelo \\
\hline erratz & escoba & sorgin & bruja \\
\hline hondartza & playa & uhin & onda \\
\hline gatazka & disputa & etsai & enemigo \\
\hline heriotza & muerte & alargun & viuda \\
\hline gizaki & hombre & isats & cola \\
\hline hiztegi & diccionario & hitz & palabra \\
\hline alkandora & camisa & oihal & tela \\
\hline zentzumen & sentido & gor & sordo \\
\hline gizon & hombre & bizar & barba \\
\hline adibide & ejemplos & eredu & modelo \\
\hline ardi & oveja & gazta & queso \\
\hline liburu & libro & egile & autor \\
\hline alkate & alcalde & herri & pueblo \\
\hline hodei & nube & lanbro & niebla \\
\hline lasterbide & atajo & bide & camino \\
\hline
\end{tabular}




\begin{tabular}{|c|c|c|c|}
\hline erreka & arroyo & zubi & puente \\
\hline zuri & blanco & elur & nieve \\
\hline sagardotegi & sidreria & afari & cena \\
\hline zotin & hipo & izualdi & susto \\
\hline biloba & nieto & ondore & descendencia \\
\hline azal & piel & bigun & blando \\
\hline jaka & cazadora & patrika & bolsillo \\
\hline eraikin & edificio & atari & portal \\
\hline gosari & desayuno & gurin & mantequilla \\
\hline lasto & paja & saski & cesta \\
\hline kaiola & caja & untxi & conejo \\
\hline oihan & selva & basati & salvaje \\
\hline inurri & hormiga & apur & miga \\
\hline helburu & objetivo & gailur & cima \\
\hline bizitza & vida & hiri & ciudad \\
\hline zaldi & caballo & behor & yegua \\
\hline argi & luz & leiho & ventana \\
\hline $\begin{array}{c}\text { Haserre } \\
\text { hotz }\end{array}$ & $\begin{array}{l}\text { enfado } \\
\text { frio }\end{array}$ & $\begin{array}{l}\text { frustrazio } \\
\text { tenperatura }\end{array}$ & $\begin{array}{l}\text { frustracion } \\
\text { temperatura }\end{array}$ \\
\hline landare & planta & lore & flor \\
\hline beso & brazo & ukondo & codo \\
\hline hauteskunde & elecciones & gobernu & gobierno \\
\hline laguntasun & amistad & sekretu & secreto \\
\hline zorro & billetera & diru & dinero \\
\hline arazo & problema & abokatu & abogado \\
\hline erosketa & compra & prezio & precio \\
\hline zakarrontzi & basura & botila & botella \\
\hline komentu & conventos & moja & monja \\
\hline errege & rey & balkoi & balcón \\
\hline biztanleria & población & mundu & mundo \\
\hline irakasle & profesor & eskola & escuela \\
\hline basamortu & desierto & oasi & oasis \\
\hline harri & piedra & zementu & cemento \\
\hline orekari & equilibrista & zirku & circo \\
\hline neska & chica & dontzeila & doncella \\
\hline ikerketa & investigacion & esperimentu & experimento \\
\hline $\mathrm{su}$ & fuego & infernu & infierno \\
\hline okin & panadero & irin & harina \\
\hline bihotz & corazón & pultsu & pulso \\
\hline ohitura & costumbre & erritu & rito \\
\hline borroka & lucha & ezpata & espada \\
\hline kutxazain & cajero & banku & banco \\
\hline ordu & hora & minutu & minuto \\
\hline udare & pera & limoi & limón \\
\hline hitzaldi & discurso & mutu & mudo \\
\hline arrantza & pesca & portu & puerto \\
\hline galdetegi & cuestionario & inkesta & encuesta \\
\hline zauritu & ruido & anbulantzia & ambulancia \\
\hline azkazal & uña & katu & gato \\
\hline hori & amarillo & kolore & color \\
\hline
\end{tabular}




\begin{tabular}{|c|c|c|c|}
\hline zuku & zumo & kafetegi & cafetería \\
\hline izar & estrella & espazio & espacio \\
\hline arotz & carpintero & zerra & sierra \\
\hline irribarre & sonrisa & umore & humor \\
\hline euskara & vasco & frances & francés \\
\hline tximu & mono & eboluzio & evolución \\
\hline talde & grupo & zeremonia & ceremonia \\
\hline sukalde & cocina & txalet & chalet \\
\hline muga & frontera & probintzia & provincia \\
\hline urre & oro & brontze & bronce \\
\hline gezi & flecha & arku & arco \\
\hline ikasle & estudiante & paper & papel \\
\hline bidaia & viaje & pilotu & piloto \\
\hline ardo & vino & likore & licor \\
\hline beldur & miedo & munstro & monstruo \\
\hline albiste & noticia & informazio & información \\
\hline margolari & pintor & diseinu & diseño \\
\hline gauza & $\cos a$ & objektu & objeto \\
\hline ume & niño & kanpamentu & canpamento \\
\hline jantzi & traje & gorbata & corbata \\
\hline betile & pestaña & erretina & retina \\
\hline salda & caldo & zopa & sopa \\
\hline hezkuntza & educación & dialektika & dialéctico \\
\hline korrikalari & corredor & maratoi & maraton \\
\hline iltze & clavo & mailu & martillo \\
\hline inurri & hormiga & intsektu & insecto \\
\hline barazki & vegetal & fruitu & fruta \\
\hline garratz & amargo & zapore & sabor \\
\hline aingeru & ángel & deabru & diablo \\
\hline denbora & tiempo & erloju & reloj \\
\hline esne & leche & kaltzio & calcio \\
\hline ehun & cien & mila & mil \\
\hline egunkari & periodico & prentsa & prensa \\
\hline karratu & cuadrado & angelu & ángulo \\
\hline heldu & adulto & esperientzia & experiencia \\
\hline guraize & tijeras & mozte & corte \\
\hline gezur & mentira & faltsu & falso \\
\hline apaiz & sacerdote & santu & santo \\
\hline kotoi & algodón & zeta & seda \\
\hline jatetxe & restaurante & plater & plato \\
\hline hizkuntza & idioma & azentu & acento \\
\hline langile & trabajador & sindikatu & sindicato \\
\hline txiki & pequeño & baxu & bajo \\
\hline erizain & enfermera & doktore & doctor \\
\hline saiakera & intento & konpromiso & compromiss \\
\hline garraio & transporte & bizikleta & bicicleta \\
\hline agure & anciano & beterano & veterano \\
\hline bular & pechos & abdomen & abdomen \\
\hline ipar & norte & hemisferio & hemisferio \\
\hline baratze & huerta & tomate & tomate \\
\hline
\end{tabular}




\begin{tabular}{|c|c|c|c|}
\hline opari & regalo & pakete & paquete \\
\hline idazlan & redacción & letra & letra \\
\hline loreontzi & florero & tulipa & tulipa \\
\hline baratxuri & ajo & menta & menta \\
\hline artizar & venus & astro & astro \\
\hline arraun & remo & kanoa & canoa \\
\hline arkatz & lápiz & koaderno & cuaderno \\
\hline txirula & flauta & piano & piano \\
\hline izeba & tía & familia & familia \\
\hline maitasun & amor & poema & poema \\
\hline txanpon & moneda & kasino & casino \\
\hline iparorratz & brujula & mapa & mapa \\
\hline lehoi & leone & tigre & tigre \\
\hline usain & oler & perfume & perfume \\
\hline negar & llanto & tragedia & tragedia \\
\hline ostiral & viernes & taberna & taberna \\
\hline abeslari & cantante & disko & disco \\
\hline argazki & fotografía & galeria & galería \\
\hline altxor & tesoros & pirata & pirata \\
\hline gidari & conductor & autobus & autobus \\
\hline abiadura & velocidad & radar & radar \\
\hline zaldun & caballero & armadura & armadura \\
\hline lekuko & testigo & krimen & crimen \\
\hline pilula & pastilla & gripe & gripe \\
\hline nahaste & trastorno & kaos & caos \\
\hline mezu & código & morse & morse \\
\hline gaixotasun & enfermedad & malaria & malaria \\
\hline joku & juego & dado & dado \\
\hline harrera & recepción & hotel & hotel \\
\hline etaurrekoak & gafas & optiko & óptico \\
\hline itsaso & mar & marea & marea \\
\hline berdin & igual & simetria & simetria \\
\hline lepoko & colgante & diamante & diamante \\
\hline aldizkari & revista & propaganda & propaganda \\
\hline babes & protección & kasko & casco \\
\hline herrialde & país & bandera & bandera \\
\hline ur & agua & dutxa & ducha \\
\hline odol & sangre & kolesterol & colesterol \\
\hline saihets & costilla & tibia & tibia \\
\hline zigor & castigo & tortura & tortura \\
\hline emakume & mujer & hormona & hormona \\
\hline orein & ciervo & fusil & fusil \\
\hline edari & bebida & kopa & copa \\
\hline aztikeri & hechizo & magia & magia \\
\hline burdin & hierro & metal & metal \\
\hline arrisku & peligro & eskolta & escolta \\
\hline ke & humo & tabako & tabaco \\
\hline elikadura & nutrición & bitamina & vitamina \\
\hline begi & ojo & iris & iris \\
\hline abesti & cancion & poesia & poesia \\
\hline
\end{tabular}




\begin{tabular}{cccc} 
bake & paz & espiritual & espiritual \\
lasaitasun & tranquilidad & monasterio & monasterio \\
itzal & sombra & silueta & silueta \\
lauki & cuadrado & forma & forma \\
igerilari & nadador & atleta & atleta \\
lege & ley & notario & notario \\
saskibaloi & baloncesto & bola & bola \\
argal & delgado & dieta & dieta \\
zor & deuda & tarifa & tarifa \\
hezur & hueso & eskeleto & esqueleto \\
konorte & conciencia & koma & coma \\
arnas & respiración & karbono & carbono \\
haragi & carne & proteina & proteina \\
gorputz & cuerpo & organo & organo \\
kirolari & deportista & tenis & tenis \\
hegazkin & avión & maleta & maleta \\
hari & cuerda & gitarra & guitarra \\
zenbaki & número & inbentario & inventario \\
erakusketa & exposición & arte & arte \\
lamia & sirena & mitologia & mitologia \\
ipuin & cuento & literatura & literatura \\
norabide & dirección & labirinto & labirinto \\
hezetasun & humedad & klima & clima \\
puxika & globo & helio & helio \\
lapiko & hervidor & te & te \\
geltoki & estación & tren & tren \\
txerto & vacuna & diabete & diabete \\
errepide & carretera & taxi & taxi \\
\hline & & &
\end{tabular}




\section{Noise Mixing Procedure}

For Experiment 1, targets were mixed with reversed Basque 6-talker speech babble ${ }^{2}$ at a signal-to-noise ratio of $-5 \mathrm{~dB}$. The procedure for mixing the noise with the stimuli was as follows. First, the stimuli were trimmed to remove silence from the beginning and end of the audio recordings. The stimuli were then matched in volume using a function in GoldWave "Match Vol" that matches the root mean square to the same value (Goldwave Version 6.15 Computer software, www.goldwave.com). The word target stimuli were then mixed with unique segments of noise using a Praat script which added an additional $50 \mathrm{msec}$ of noise before and after the target. The $50 \mathrm{msec}$ segments of noise at the beginning and end of the recordings were gradually faded in and out, using the "fade in" and "fade out" linear functions in Goldwave. Unique segments of noise were used for each word target. The same segments were mixed with the pseudoword targets but words and pseudowords with the same noise segments were counterbalanced across participants. Note that because of the leading and trailing $50 \mathrm{~ms}$ noise segments, stimulus durations were 100 ms longer in Experiment 1 than in Experiment 2.

\footnotetext{
${ }^{2}$ The babble-noise was constructed following the procedure used in Dole, Hoen, and Meunier (2012). Six speakers (three males, three females) were recorded in a soundproof room while reading passages of Basque newspapers. From these individual six recordings, silences of more than one second were removed. Fragments containing pronunciation errors or exaggerated prosody were also discarded. We then applied noise reduction to eliminate artifact interference for each of the six individual tracks, and, finally, mixed the tracks to create the 6-talker babble.
} 


\section{Mixed linear effects analyses ${ }^{3}$}

\section{Table A}

\begin{tabular}{|c|c|c|c|}
\hline \multicolumn{4}{|c|}{ Experiment 1 Lexical Decision (Accuracy) $^{4}$} \\
\hline & Effect & CI & $p$ \\
\hline & Relatedness & {$[1.18,1.44]$} & $<.001$ \\
\hline & Cognate Status & {$[0.66,0.91]$} & .002 \\
\hline & Relatedness $*$ CognateStatus & {$[1.02,1.24]$} & .017 \\
\hline \multicolumn{4}{|l|}{ Model } \\
\hline \multirow[b]{3}{*}{ Finer Grained } & Relatedness & {$[1.23,1.51]$} & $<.001$ \\
\hline & Contrast 1: Partial vs. Noncognate & {$[0.75,1.22]$} & .71 \\
\hline & Contrast 2: Identical vs. Noncognate & {$[0.59,0.95]$} & .02 \\
\hline & Related $*$ Contrast 1 & {$[0.98,1.33]$} & .10 \\
\hline & Related $*$ Contrast 2 & {$[0.89,1.2]$} & 67 \\
\hline \multicolumn{4}{|c|}{$\begin{array}{l}\text { Model } \\
<- \text { glmer(Accuracy } \sim \text { Relatedness * TypeOfCognate+ TargetDuration }+(1 \mid \text { Participant })+(1 \mid \text { Item })) \text {, family=binomial }\end{array}$} \\
\hline \multicolumn{4}{|c|}{ Experiment 1 Long-term Priming } \\
\hline & Old/New & {$[0.82,0.95]$} & $<.001$ \\
\hline & Cognate Status & {$[0.67,0.95]$} & .009 \\
\hline & OldNew $*$ Cognate Status & {$[0.86,0.99]$} & .024 \\
\hline
\end{tabular}

Model

<- glmer(Accuracy OldNew * CognateStatus+ TargetDuration + (1|Participant $)+(1 \mid$ Item $)$ ), family=binomial

\section{Old Items Only}

Relatedness

$[0.96,1.17]$

.246

Cognate Status

$[0.71,1.02]$

Relatedness * Cognate Status

$[0.98,1.19]$

Model

<- glmer(Accuracy Relatedness * CognateStatus + TargetDuration + (1|Participant $)+(1 \mid$ Item $))$, family=binomial

\section{New Items Only}

$$
\text { Cognate Status [0.64-0.93] }
$$

.007

Model

$<-$ glmer(Accuracy CognateStatus+ TargetDuration + (1|Participant $)+(1 \mid$ Item $)$, family=binomial

${ }^{3}$ Model comparisons were performed using likelihood ratio tests and a forward-testing approach maximizing the effects structure (Baayen et al., 2008; Barr et al., 2013). More complex models were disregarded only if the p-value for the significance of the difference was above 0.20 (Matuschek, Kliegl, Vasishth, Baayen, \& Bates, 2017). All models were best fit by including by Item and by Subject random intercepts.

${ }^{4}$ Reaction Time Analysis for correct responses in Experiment 1

54
55
56
57
58
59

\section{Experiment 1 (Reaction Time)}

\begin{tabular}{lcc}
\multicolumn{1}{c}{ Effect } & CI & $\boldsymbol{p}$ \\
Relatedness & {$[-28.95,-1.33]$} & .03 \\
Cognate Status & {$[10.49,44.06]$} & .002
\end{tabular}

Model

$<-\operatorname{lmer}($ Accuracy $\sim$ Relatedness + CognateStatus + TargetDuration $+(1 \mid$ Participant $)+(1 \mid$ Item $))$ 
Table B

\begin{tabular}{|c|c|c|c|}
\hline \multicolumn{4}{|c|}{ Experiment 2 Lexical Decision (Reaction Time) } \\
\hline & Effect & CI & $p$ \\
\hline & Relatedness & {$[-26.09,10.02]$} & $<.001$ \\
\hline & Cognate Status & {$[5.94,40.48]$} & 0.01 \\
\hline \multicolumn{4}{|c|}{$<-\operatorname{lmer}($ ReactionTime $\sim$ Relatedness + CognateStatus + TargetDuration $+($ CognateStatus $\mid$ Participant $)+(1 \mid$ Item $))$} \\
\hline & Relatedness & {$[-26.15,-10.34]$} & $<.001$ \\
\hline & Contrast 1: Partial vs. Noncognate & {$[-19.92,13.84]$} & .73 \\
\hline Finer Grained & Contrast 2: Identical vs. Noncognate & {$[6.90,57.78]$} & .015 \\
\hline \multicolumn{4}{|l|}{ Model } \\
\hline \multicolumn{4}{|c|}{ Experiment 2 Long-term Priming } \\
\hline & Old:New & {$[22.71,33.55]$} & $<.001$ \\
\hline & CognateStatus & {$[-5.31-13.35]$} & .4 \\
\hline & OldNew:CognateStatus & {$[-4.53-6.31]$} & .75 \\
\hline \multicolumn{4}{|c|}{$\begin{array}{l}\text { Model } \\
<-\operatorname{lmer}(\text { ReactionTime } \sim \text { OldNew + CognateStatus + TargetDuration+ (1|Participant)+(1|Item)) } \\
\text { Old Items Only }\end{array}$} \\
\hline Relatedness & & {$[-2.16-12.65]$} & .17 \\
\hline CognateStatus & & {$[-7.27-16.03]$} & .46 \\
\hline Relatedness:Co & & {$[-5.73-9.07]$} & .66 \\
\hline \multicolumn{4}{|c|}{$\begin{array}{l}\text { Model } \\
<-\operatorname{lmer}(\text { ReactionTime } \sim \text { OldNew + CognateStatus + TargetDuration+ }(\text { CognateStatus|Participant })+(1 \mid \text { Item }))\end{array}$} \\
\hline \multicolumn{4}{|c|}{ New Items Only } \\
\hline & Cognate Status & {$[-8.39-15.66]$} & .55 \\
\hline $\begin{array}{l}\text { Model } \\
<-\operatorname{lmer}(\text { Reactio }\end{array}$ & gnateStatus + TargetDuration+ (1|Par & n)) & \\
\hline
\end{tabular}

\section{References}

Baayen, R. H., Davidson, D. J., \& Bates, D. M. (2008) Mixed-effects modeling with crossed random effects for subjects and items. Journal of Memory and Language, 59, 390-412.

Barr, D. J., Levy, R., Scheepers, C., \& Tily, H. J. (2013). Random effects structure for confirmatory hypothesis testing: Keep it maximal. Journal of memory and language, 68(3), 255-278.

Matuschek, H., Kliegl, R., Vasishth, S., Baayen, H., \& Bates, D. (2017). Balancing Type I error and power in linear mixed models. Journal of Memory and Language, 94, 305-315. 